\title{
National Child Care Standards: Protecting America's Children
}

Alena Svabt

Alena Svab will

complete her master of public administration

degree with a

concentration in

business-government

relations in 1998.

During her graduate

studies, she also

served as a GW

Presidential

Administrative Fellow.

Mo. Suab received her

bachelor's degree in

international affairs

and french from the

George Washington

University in 1996.

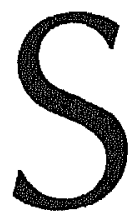

amantha, a mother of three pre-schoolers in Oregon, rises before dawn to get her children ready for another day at the nearby Young Stars day care center, a bright and cheerful facility. After a long day at work, she returns to find that her three youngsters have spent an enjoyable and productive day at the center learning arts and crafts, singing songs, and listening to stories. The staff at Young Stars, who are trained in early childhood development, continually plan new and exciting activities for the children. While Samantha is at work, she knows her children are safe because the Young Stars facility is inspected and licensed regularly by inspectors who enforce the compliance standards of Oregon's strict child care licensing regulations.

Joanne, a mother of three pre-schoolers in Mississippi, rises before dawn as well. Unlike her counterpart in Oregon, Joanne spends the next two hours calling everyone she knows to find a caretaker for her children while she is at work, a search that is the result of her bad experiences with local day care facilities. 
Wide disparities

exist in child

care safety and

quality among

the fifty states.
The centers were all very different, ranging from several rooms in a finished basement to a converted storefront operation. None of the facilities seemed clean or safe, and too many children ran around unsupervised as an overburdened staff tried to deal with immediate crises. Joanne's children often came home from these centers with food stains on their faces and clothes, dirty hands and irritable tempers. They were bored from long days of doing nothing but fighting over old toys with other children at the centers. Victim of a patchwork of indifferent state services which provide few standards for child care centers or their staff, Joanne has to hope each day that someone will be able to care for her children while she works to provide for the family.

As these examples illustrate, wide disparities exist in child care safety and quality among the fifty states. To make matters worse, not only do state child care standards differ greatly but those standards that do exist are often not enforced adequately. The disparity in standards is a serious public problem because children without access to safe and high-quality child care do not receive the necessary non-parental care to develop into healthy and successful adults.

As the trustee of the health and safety of the American public, the federal government has a vested interest in ensuring that safe and highquality child care is available to all its citizens. Accordingly, the federal government should establish national child care standards to ensure that safe and high-quality child care is available to those families who choose to use these services. It is important to note that parental choice is an integral component of the child care policy debate, and no government agency can stipulate that children must be in child care facilities. ${ }^{1}$

\section{Scope of Analysis}

In this article, child care is defined as non-parental care of pre-kindergarten-age children that is provided at specialized child care facilities or at the home of a caregiver and is provided to children of two or more families at a time. This analysis does not address child care problems of stayat-home parents, relatives who provide child care for family members, nannies, au pairs, and other caregivers who take care of only one family's children in the family's home. In addition, child care issues involving pre-schools, kindergartens, primary schools, and secondary schools are not addressed in this article. Additionally, this article utilizes the words "child care guidelines" and "child care standards" interchangeably and advocates the establishment of national child care standards. Issues of the implementation, administration, enforcement, and funding of national standards for child care facilities are not discussed in detail in this analysis.

High-quality child care provides a safe, nurturing, and stimulating environment for children. The child Welfare League, a national child advocacy group, maintains that the 
quality of child care is "primarily related tó higher staff-to-child ratios, staff education, and administrators' prior experiences." 2 This article suggests that two conditions must be met to ensure that a child care facility is high-quality. First, the facility must employ trained and certified child care personnel who spend a prescribed amount of time each day engaged in developmental and learning activities with the children. ${ }^{3}$ Second, the facility must be safe, clean, and free of dangerous materials and fire hazards. Additionally, in a safe child care facility, a limit exists on the maximum number of children for each child care worker.

\section{Background}

Over the last twenty years, child care concerns have evolved from a "women's issue" into a topic of highprofile national policy debate. More children are in daily out-of-home care now than twenty years ago because more mothers work outside the home on a regular basis. 4 However, the same forces of change that have increased the number of women in the workforce have not kept pace with the need to provide safe and highquality care for their children. Greater public attention has revealed that child care in the United States frequently does not meet basic safety and quality standards.

Recently, child care issues, including the inconsistency and inefficiency of state child care standards, have garnered increasing public attention. In 1997 alone, members of
Congress introduced thirty-five bills which addressed various aspects of child care policy, including tougher enforcement of existing state safety and quality standards, as well as the establishment and enforcement of uniform standards at child care centers located on federal property. ${ }^{5}$ In March 1998, President Clinton publicly endorsed the latter by announcing a new White House focus to ensure that federal child care facilities are accredited by non-profit agencies that monitor quality at child care centers. ${ }^{6}$

President Clinton's statement in March 1998 was not the only recent White House initiative on this topic. Following an October 1997 White House Conference on Child Care, President Clinton introduced in January 1998 a plan to address the national "crisis in child care." The $\$ 21.7$ billion five-year package includes $\$ 3$ billion to improve the quality of child care by providing child care staff training, helping child care personnel meet state accreditation and licensing requirements, and improving childto-staff ratios. The president's proposal also includes $\$ 500$ million to enforce existing state child care licensing procedures and existing state health and safety standards. ${ }^{8}$

Several factors account for the increased attention on child care issues. First, child care has emerged on the political agenda due to the 1996 Personal Responsibility and Work Opportunity Reconciliation Act. With its focus on transitioning more people off welfare and into the workforce,
In 1997 alone, members of

Congress

introduced thirty-

five bills which

addressed

various aspects

of child care

policy. 
Today, nearly

thirteen million

children under

age six are in

child care on a

daily basis. the need for more child care for their children has increased. The new welfare law has thus been a major impetus for the current public dialogue on child care and has helped propel the issue into the political spotlight.

The second underlying factor in the present prominence of child care policy is the support of women, whose political influence has grown drastically over the last twenty years. In many congressional districts, women have become key voting blocs whose decisions on election day decide the fates of hundreds of hopeful politicians. In the late 1990s, women's political clout affects not just socially liberal Democrats who have traditionally sought the women's vote but also socially conservative Republicans attuned to the national mood. Thus, national politicians address child care, a topic that would not even have been included on party platforms twenty years ago.

For many child care advocates, the most compelling reason for the current national focus on child care standards is the very bleak state of child care in America. Today, nearly thirteen million children under age six are in child care on a daily basis. ${ }^{9}$ Six out of seven child care centers provide care that is mediocre to poor, and one in eight centers provide care that could jeopardize children's safety and development. ${ }^{10}$ As evident from the examples at the beginning of this article, wide disparities in the basic health and safety standards for child care exist between many states and even high standards for child care are often not enforced by the states. Accordingly, this issue must be addressed at the national level to change the current hodge podge of state and local child care standards to ensure greater consistency in the availability of safe and high-quality care for future generations of Americans.

\section{The Current Federal Role in Child Care Policy}

The current involvement of the federal government in child care policy is limited to a mix of tax incentives, block grant funding to the states, and provision of support services, Most of the federal child care policies focus on welfare recipients, on those transitioning off welfare, and on low-income families. The Dependent Care Tax Credit and the Child Care and Development Block Grant (CCDBG) represent the largest portion of federal child care spending. 11 Under the 1996 Personal Responsibility and Work Opportunity Reconciliation Act, the CCDBG provides $\$ 4$ billion in block grants over a six-year period to states to provide child care assistance to low-income working families and welfare recipients who are leaving welfare. ${ }^{12}$ So important is CCDBG as an effort to devolve fiscal and administrative responsibility for social programs to the states that many of the thirty-five child care bills introduced in Congress in 1997 advocate substantial increases in the CCDBG. ${ }^{13}$

The federal government stipulates that federal $C C D B G$ funds be 
used only in settings that meet existing minimum state health and safety standards but also allows the states to determine these standards, including state licensing - where it is available - and other state guidelines. ${ }^{14}$ The federal government also requires states to set aside at least four percent of federal child care funding each year to improve the quality and supply of child care but allocation of these funds is also left to state discretion. ${ }^{15}$

\section{The Case for Federal Child Care Standards}

The development of America's children and the kind of child care they receive from non-parental caregivers are inexorably linked. New research has determined that childhood development between birth and three years of age is vital to the foundation of mentally and emotionally healthy individuals. Additionally, other research has indicated that lowquality child care has a negative effect on the development of young children in their crucial formative years. Children in poor quality child care have been found to be delayed in language and reading skills and display more aggression toward other children and adults. ${ }^{16}$ As the number of children in child care increases, the importance of this link between child care and future adult life becomes more important.

The federal government spends billions of dollars on child care funding but has little or no control over how these funds are spent. Although
Congress and the president advocate increased federal block grant funding for state child care policies (including enforcement of existing state child care guidelines), state child care guidelines vary significantly; in fact, many fail to meet nationally recognized health, salety, and quality standards developed by organizations such as the National Association for the Education of Young Children (NAEYC), which provide specific standards needed to qualify for child care licensing in certain states. ${ }^{17}$ Consequently, child care in the United States is a "patchwork of policies where each state does its own thing." 18

Currently, the federal government lacks the legislative authority to improve the dismal state of child care standards around the country. However, the government has both the constitutionally derived authority to protect the safety, health, and welfare of all citizens and the means, through block grants, to establish national guiclelines over the spending of federal dollars in the child care field. For these reasons, the federal government must change its role in child care policy to establish national child care safety and quality standards to ensure the availability of safe and effective child care to those who choose to use this service.

The establishment of national child care guidelines will not impede the current political trend toward policy devolution to the states nor will it permit federal administration of child care policies in each state. Instead,
Children in poor

quality child care

have been found

to be delayed in

language and

reading skills and

display more

aggression

toward other

children and

adults. 
The federally established, nationally recognized child care safety and quality guidelines would be implemented and enforced by the states, with federal support if necessary. the federally established, nationally recognized child care safety and quality guidelines would be implemented and enforced by the states, with federal support if necessary. Existing high-quality state child care standards could be used as the model for the establishment of fecleral child care guidelines. States would comply with these federal standards much as they comply with fecleral standards in many other public welfare and safety areas, including occupational safety standards and school meal guidelines.

The 1997 White House Conference on Child Care highlighted the position of several influential child care advocacy groups, including the Child Welfare League, which encourage a federal role in ensuring the safety and quality of child care provided by the states and localities. These groups propose that the federal government develop and support a professional credentialing system for child care staff, eliminate state barriers to checking criminal backgrounds of potential child care workers, increase the extremely low wage levels for child care workers, and encourage child care workers to seek specialized child care training through various incentives. In addition, these federal child care guidelines would include provisions for their enforcement by the states and localities. States would maintain their jurisdiction over the administration of their individual child care programs and over the adjustment of their state child care standards to the national guidelines,
Although this proposal does increase the role of the federal government in child care policy, the intentionally narrow focus on standards ensures that existing federal child care resources, such as the Child Care Bureau of the Department of Health and Human Services (HHS), would be sufficient to meet the new policy goals. Using existing federal resources to develop and implement national child care standards would prevent this new policy from imposing a financial burden on the federal government. HHS would also benefit from modeling the implementation and administration of national child care standards on first-rate state policies. Whatever model the federal government chooses, national standards would eliminate the wide disparities between current state and local guidelines which leave Joanne in Mississippi with vastly different child care choices than Samantha in Oregon.

\section{Federal Standards: Analysis of Precedents}

Federal regulation of social policies has decreased dramatically over the last decade due to the continuing shift of policy responsibilities to the states. This political climate continues today, with the fear of "big government" clouding many proposed federal programs. As evident from the failure of the Clinton health plan proposal, the public and representatives in Washington will not support a dramatic increase in federal involvement in a major policy issue, including 
child care. ${ }^{19}$ In order to ensure greater equity in child care availability in a politically feasible manner, the limited federal role of standard-setting is the most viable policy option.

To address reservations about the propriety of federal development and enforcement of national child care standards for the states and localities, several examples of federal standardsetting in other social policy areas are clescribed. These examples illustrate that legal, regulatory, and ethical precedents for national child care standards have been established.

\section{School meal programs:}

Established over fifty years ago and still growing, the School Lunch Program and the School Breakfast Program are examples of the federal government's establishment of standards for implementation by state and local governments. Schools that choose to provide meals to their students must follow specific nutrition and affordability guidelines established by the Child Nutrition Department of the USDA Food and Consumer Service. At the same time, the programs are state-funded and administered at the local level by School Food Authorities. ${ }^{20}$

During the 1966 congressional debates over expanding the School Lunch Program to include School Breakfast Program standards, concerns arose among many members of Congress that this expansion of federal standards would infringe on states' rights and expand the "welfare state." 21 In the end, the School Lunch
Program and School Breakfast Program have been successful, despite such political opposition, because they provide nutrition and administrative standards while allowing the states to implement the programs according to their indiviclual needs. In this example, the national standards ensure equitable availability of a service which enhances the health and welfare of millions of public and private school students nationwide.

\section{Occupational Safety and Health:}

The Occupational Safety and Health Administration (OSHA) ensures that states and individual employers comply with national occupational safety and health standards. However, the ways in which states adapt their own state standards to the federal standards vary according to the needs of each state. States may submit their own plans for ensuring workplace health and safety but these programs must be "at least as effective as" federal OSHA regulations. By implementing their own plans, states are eligible for a variety of federal funding and for exemption from certain federal regulations that may not apply. States without their own plans must comply fully with all federal OSHA regulations. ${ }^{22}$

In 1969, President Nixon proposed the Occupation Safety and Health Act that gave the states the option to administer standards set by the federal government if state laws did not meet these minimum standards. This proposal enjoyed significant support from businesses that faced a
Legal, regulatory,

and ethical

precedents for

national child

care standards

have been

established. 


\section{Enforcement of}

inadequate state

child care

standards will

not help

children. patchwork quilt of state safety laws, standards and penalties. ${ }^{23}$ Business had defeated earlier attempts to establish sweeping federal occupational health and safety regulation, charging usurpation of states' rights by the federal government. ${ }^{24}$ As a result, the Occupational Safety and Health Administration was created by Congress in 1970 after years of debate over workplace safety and worker health.

The federal workplace safety stanclards set by OSHA faced serious political opposition in the 104 th Congress. Nevertheless, the agency and its policies withstood the political test and OSHA's 1997 congressionally-approptiated budget was the highest ever, ${ }^{25}$ demonstrating the long-term viability of national occupational safety standards despite periodic political opposition. Federal OSHA guidelines continue to provide for the health and safety of the American working public while leaving administrative details under state jurisdiction.

\section{Military child care model:}

Since the passage of the 1989 Military Child Care Act, the Department of Defense (DOD) has maintained close supervision of the military Child Development Program. The DOD developed specific guidelines for child care facilities and staff at all military installations around the world. Nevertheless, individual bases still retain autonomy in developing their own child care programs based on the needs of each location. ${ }^{26}$ In the proposed federal child care over- sight role, the national stanclards would be parallel to the DOD standards set for military installations, while still allowing for local administrative control. Although the implementation and administration of military social policy differs from civilian policy, this example illustrates that local jurisdictions can comply with federal law while retaining administrative autonomy. If a centrallyadministered organization such as the military is able to ensure local administration of its child care standards, the federal government will be able to preserve states' rights in the administration of federal child care standards.

These precedents of existing and effective national standards in other social policy areas demonstrate that the federal government has a right and, more importantly, a responsibility to ensure the health, safety, and welfare of its citizens. The government is neglecting its responsibility to the American people in its failure to establish national child care standards.

\section{Conclusion}

The current state of American child care is bleak. Wide disparities exist in the availability of safe and high-quality child care among the states. As mentioned above, President Clinton and other policy makers have proposed increased funding for child care block grants to the states as well as the enforcement of existing child care standards but bigger budgets are clearly not enough to improve the dismal condition of child care quality 
and safety in America. Enforcement of inadequate state child care standards will not help children. Greater federal funding for state child care policies that do not meet nationallyrecognized quality and safety standards only places more American children in jeopardy. The federal government must do more to provide consistently safe and high-quality child care nationwide.

The federal government has the right and responsibility to provide uniform national standards to ensure basic child care safety and quality. The government's increased role in child care policy would likely receive political backing in Congress especially given the current public focus on improving child care around the country. Additionally, the examples of OSHA and the school meal programs illustrate that the proposal of national child care guidelines requiring state compliance is in accord with the fecleral government's role as the trustee of the public health, safety, and welfare.

America's children deserve access to child care that will promote their development into healthy adults. As more and more children enter child care facilities in the coming years, the importance of safe and high-quality child care will only continue to increase. By providing consistency in the national standards used to accredit and license child care providers and facilities, the federal government will ensure that safe and high-quality child care will be available nationwide. These guidelines will not only be a crucial improvement in the development of American child care but also protection for America's future generations. 4

\section{Notes}

tI would like to thank Lisa Gisvold and Meredith McWade for their tremendous help and wonderful advice on this article. Their support and hard work was invaluable. Thanks also to Rachel Stein and Jill Kasle for their insight and assistance. This article is dedicated to Jodi Reborchick, a great friend and colleague who lived through the experience of writing this article with me, as well as the past two years in the public administration program.

1 Andrew Hagan, telephone conversation with the aluthor, 28 October 1997.

2 Child Welfare League of America, "Quality Child Care Makes a Difference," Testimony submitted to the Senate Committee on Labor and Human Resources, Washington, DC, 17 July 1997.

3 Barbara Vobejda, "Who's Minding the Children?" The Wasbington Post, 22 October 1997, A1. It is difficult for most child care centers to attract personnel with child care training and experience, since the average child care worker wage is $\$ 6,89$ per hour.

${ }^{4}$ Margy Waller, "The President's Child Care Initiative: Investing in Equity," 11 March 1998; available from htp://www.cilcppi. org/texts/social/ccare98.htm; INTERNET.

5 Children's Defense Fund, "Child Care Bills Introduced in the 1st Session of Congress," 11 March 1998; available from http:// www.childrensdefense.org/co_bills.html; INTERNET.

6 John F. Harris, "Clinton Focuses on Federal Child Care," The Washington Post, 10 March 1998, A1.

7 Thid.
America's

children deserve

access to child

care that will

promote their

development into

healthy adults. 
8 Children's Defense Fund, "The President's Child Care Initiative," 11 March 1998; available from http://www.childrensdefense. org/cc_proposal.html; INTERNET.

9 News release, "Government Facts About Child Care," The Associated Press, 21 October 1997; available from http://search. washingtonpost,com; INTERNET.

10 Children's Defense Fund, "Inadequate Child Care Strains America's Working Families," 21 October 1997; available from http://www,childrensdefense.org/cc_partner s.html; INTERNET.

11 Children's Defense Fund, "Federal and State Government: Partners in Child Care," 21 October 1997; available from http://www. childrensdefense.org/cc_partners.html; INTERNET. The single largest source of federal support for child care, the Dependent Care Tax Credit (DCTC), allows families to claim an income tax credit for a portion of their child care expenses. The DCTC offsets $20-30 \%$ of a working parent's child care expenses (up to a pre-cletermined maximum) via the tax system. Most of the 6 million families who receive this credit are middleand upper-income, since the nonrefundable tax credit is not available to families that are too poor to pay taxes.

12 Andrew Hagan, telephone conversation with the author, 28 October 1997. Blockfuncled child care assistance is usually provicled on a sliding-fee basis; families pay some of the costs, with the amount rising as their incomes rise. The CCDBG consoliclated several pre-1996 child care programs for lowincome and welfare families into one program, thus reducing administrative complexity.

13 Children's Defense Fund, "Child Care Bills Introduced in the 1st Session of Congress," 11 March 1998; available from http://www,childrensdefense,org/cc_bills,ht $\mathrm{ml}$; INTERNET. These include Senator Dodd and Senator Daschle's proposal to increase funding to $\$ 10$ billion over five years.

14 Children's Defense Fund, "Federal and State Government: Partners in Child Care," 21 October 1997; available from http://www. childrensdefense.org/cc_partners.html; INTERNET.
15 Ibid. These funds support efforts such as training for child care providers and resource/referral agencies that help families transitioning off welfare to find child care.

16 Children's Defense Fund, "Inadequate Child Care Strains America's Working Families," 21 October 1997; available from http://www.childrensdefense.org/c_partners .html; INTERNET.

17 National Association for the Education of Young Children (NAEYC), "Licensing and Public Regulation of Early Chilchood Programs," 10 March 1998; available from http://www.naeyc.org/about/position/pslice nse.htm; INTERNET.

18 Suzanne Reichmann, telephone conversation with the author, 5 November 1997.

19 Ibid.

20 Code of Federal Regulations, "School Breakfast Program Regulations; 7 CFR Section 220.4" (Washington, DC: Government Printing Office, revised as of I January 1996) 8.

21 Congressional Record, 89th Cong., $2 \mathrm{~d}$ sess., 1966, 112, pt.12: S 20176.

22 Benjamin W. Mintz, OSHA: History, Law and Policy, (Washington, DC: The Bureau of National Affairs, Inc, 1984) xi.

23 Ibid., xii.

24 Ibid, 619.

25 Occupational Safety and Health Review Commission, Guide to Review Commission Procedures (Washington, DC; OSHA, 1997).

26 U.S. Department of Defense, "Military and Civilian Child Care Partnerships: Overview of the DOD Child Development System, " 28 October 1997; available from http://dticaw.dtic.mil/childcare/partnerships, html\#1; INTERNET. 


\section{BIBLIOGRAPHY}

Child Welfare League of America. "Quality Child Care Makes a Difference," Testimony submitted to the Senate Committee on Labor and Human Resources. Washington, DC. 17 July 1997.

Children's Defense Fund. "Child Care Bills Introduced in the 1st Session of Congress." (11 March 1998). Available from http://www.childrensdefense.org/ cc_bills, html; INTERNET.

" "The President's Child Care Initiative." (11 March 1998). Available from http://www.chilclrens defense.org/cc_proposal.html; INTERNET.

. "Inadequate Child Care Strains America's Working Families." (21 October 1997). Available from http://www.childrensdefense.org/ ce_partners.html; INTERNET.

"Federal and State Government: Partners in Child Care." (21 October 1997). Available from http://www,childrensdefense.org/cc_par tners.html; INTERNET.

Code of Federal Regulations. "School Breakfast Program Regulations: 7 CFR Section 220.4" (Washington, DC: Government Printing Office, revised as of January 1, 1996) 8.

Congressional Record. 89th Cong. 2d sess. 1966. 112. pt.12: S 20176.

Hagan, Andrew. Telephone conversation with the author, 28 October 1997.

Harris, John F. "Clinton Focuses on Fecleral Child Care." The Wasbington Post. 10 March 1998. Al.
Mintz, Benjamin W. OSHA: History, Law and Policy. Washington, DC: The Bureau of National Affairs, Inc., 1984.

National Association for the Education of Young Children (NAEYC). "Licensing and Public Regulation of Early Childhood Programs." (10 March 1998). Available from http:/www.naeyc.org/ about/position/pslicense.htm; INTERNET.

News release, "Government Facts About Child Care." The Associated Press. (21 October 1997). Available from http:// search washingtonpost.com; IN"TERNET.

Occupational Safety and Health Review Commission. Guide to Review Commission Procedures. Washington, DC: OSHA, 1997.

Reichmann, Suzanne. Telephone conversation with the author. 5 November 1997.

U.S. Department of Defense. "Military and Civilian Child Care Partnerships: Overview of the DoD Child Development System." (28 October 1997). Available from http://dticaw. ctic.mil/childcare/partnerships.html\#1; INTERNET.

Vobejda, Barbara. "Who's Minding the Children?" The Wasbington Post. 22 October 1997. Al.

Waller, Margy. "The Presiclent's Child Care Initiative: Investing in Equity." (11 March 1998). Available from http:/ www. dlcppi.org/texts/social/ccares8.htm; INTERNET. 
